\title{
SALINE WATER IRRIGATION AND NITROGEN FERTILIZATION ON THE CULTIVATION OF COLORED FIBER COTTON ${ }^{1}$
}

\author{
GEOVANI SOARES DE LIMA ${ }^{2 *}$, ADAAN SUDARIO DIAS ${ }^{2}$, HANS RAJ GHEYI ${ }^{3}$, LAURIANE ALMEIDA DOS \\ ANJOS SOARES ${ }^{2}$, ELYSSON MARCKS GONÇALVES ANDRADE ${ }^{2}$
}

\begin{abstract}
In Northeast Brazil, the cultivation of colored fiber cotton has stood out as one of the agricultural activities of expressive importance because its fiber has various applications in the industry and it is a labor-demanding crop. In this context, this study aimed to evaluate the growth, water consumption, water use efficiency and production of the colored fiber cotton cv. 'BRS Rubi', as a function of saline water irrigation and nitrogen $(\mathrm{N})$ doses. The experiment was conducted in lysimeters, under greenhouse conditions, in eutrophic Regolithic Neosol, with a sandy loam texture, in Campina Grande-PB, Brazil. The plants were irrigated using water with electrical conductivities (ECw) of 5.1, 6.1, 7.1, 8.1 and $9.1 \mathrm{dS} \mathrm{m}^{-1}$ and fertilized with $\mathrm{N}$ doses (ND) of $65,100,135,170$ and $205 \mathrm{mg} \mathrm{N} \mathrm{kg}^{-1}$ soil, in a completely randomized block design, with three replicates. Irrigation using water with an $\mathrm{ECw}$ above $5.1 \mathrm{dS} \mathrm{m}^{-1}$, hampered growth, water consumption and water use efficiency of 'BRS Rubi' cotton. Among the organs, the cotton root system was less affected by the salt stress in comparison to the shoots. $\mathrm{N}$ fertilization did not mitigate the deleterious effect of salt stress on cotton growth, water consumption, water use efficiency and production. The interaction between water salinity and $\mathrm{N}$ fertilization had positive effects on total weight of seeds and lint, and the highest values were obtained in plants irrigated with water of ECw 7.6 and $7.5 \mathrm{dS} \mathrm{m}^{-1}$ and ND of $65 \mathrm{mg} \mathrm{N} \mathrm{kg}^{-1}$ of soil.
\end{abstract}

Keywords: Gossypium hirsutum L.. 'BRS Rubi'. Salt stress. Nitrogen.

\section{IRRIGAÇÃO COM ÁGUAS SALINAS E ADUBAÇÃO NITROGENADA NO CULTIVO DO ALGODOEIRO DE FIBRA COLORIDA}

\begin{abstract}
RESUMO - No Nordeste do Brasil, a cotonicultura de fibra colorida tem se destacado como uma das atividades agrícolas de expressiva importância, devido a sua fibra possuir várias aplicações na indústria, e ser uma cultura absorvedora de mão-de-obra. Neste contexto, objetivou-se com este trabalho avaliar o crescimento, o consumo hídrico, a eficiência no uso da água e a produção do algodoeiro cv. BRS Rubi de fibra colorida em função da irrigação com águas salinas e doses de nitrogênio, em experimento desenvolvido em lisímetros sob condições de casa de vegetação em Neossolo Regolítico Eutrófico de textura franco-arenosa em Campina Grande-PB. As plantas foram irrigadas com água de condutividade elétrica da água - CEa de 5,1;6,1;7,1;8,1 e $9,1 \mathrm{dS} \mathrm{m}^{-1}$ e adubadas com doses de nitrogênio - DN de $65 ; 100 ; 135 ; 170$ e $205 \mathrm{mg} \mathrm{de} \mathrm{N} \mathrm{kg}^{-1}$ de solo, no delineamento em blocos inteiramente casualizados, com três repetições. A irrigação com águas de CEa acima de $5,1 \mathrm{dS} \mathrm{m}^{-1}$ prejudicou o crescimento, o consumo hídrico e a eficiência no uso da água do algodoeiro cv. BRS Rubi; dentre os órgãos, o sistema radicular do algodoeiro foi menos afetado pelo o estresse salino em comparação com a parte aérea; a adubação nitrogenada não mitigou o efeito deletério do estresse salino sobre o crescimento, consumo hídrico, eficiência no uso da água e a produção do algodoeiro; a interação entre a salinidade da água e a adubação nitrogenada exerceu efeitos positivos na massa total de sementes e de pluma, sendo os maiores valores obtidos nas plantas irrigadas com CEa de 7,6 e 7,5 dS m${ }^{-1}$ e dose de $65 \mathrm{mg} \mathrm{N} \mathrm{kg}^{-1} \mathrm{de}$ solo.
\end{abstract}

Palavras-chave: Gossypium hirsutum L.. BRS Rubi. Estresse salino. Nitrogênio.

\footnotetext{
${ }^{*}$ Corresponding author

${ }^{1}$ Received for publication in $09 / 14 / 2016$; accepted in 03/15/2017.

Paper extracted from the postdoctoral research of the first author

${ }^{2}$ Center of Technology and Natural Resources, Universidade Federal de Campina Grande, Campina Grande, PB, Brazil; geovanisoareslima@gmail.com, sudario_dias@hotmail.com, laurispo.agronomia@gmail.com, elyssonmarcks@yahoo.com.br.

${ }^{3}$ Nucleus of Soil and Water Engineering, Universidade Federal do Recôncavo da Bahia, Cruz das Almas, BA, Brazil; hans@pq.cnpq.br.
}

Rev. Caatinga, Mossoró, v. 31, n. 1, p. 151 - 160, jan. - mar., 2018 


\section{INTRODUCTION}

In the semi-arid region of Northeast Brazil, low rainfall, irregular rainfall distribution and intense evaporation occur throughout the year. Moreover, the availability of water to agriculture has been gradually reduced in both quality and quantity, thus, it becomes necessary to use water with high salt concentrations to meet the irrigation demand (SILVA et al., 2014). However, the saline concentration can limit the growth and production of the crops, due to the reduction in the osmotic potential in the root environment and simultaneous occurrences of ionic toxicity and nutritional imbalances (KHAN; PANDA, 2008; ROSALES et al., 2012). In addition, the excess salts may cause anatomical modifications and changes in the physiological and biochemical functions of the plants, leading to adverse effects on cell water relations, with reductions in the absorption and utilization of nutrients that are essential to the plants.

In the semi-arid areas of Northeast Brazil, the cotton crop (Gossypium hirsutum L.) stands out as one of the main crops for its social and economic value. In Brazil, cotton is the basic raw material of the agrotextile chain, representing about $90 \%$ of the total natural fibers consumed and produced nationwide (ECHER et al., 2010). Other important advantages, are the use of the cotton seeds, generating lint, added-value edible oil for human consumption and cotton cake to complement the cattle diet (JERÔNIMO et al., 2014).

The cotton crop stands out for its salt tolerance (AYERS; WESTCOT, 1999). The crop expresses a potential $(100 \%)$ yield at up to $7.7 \mathrm{dS} \mathrm{m}^{-1}$ electrical conductivity (ECw) in the soil saturation extract of $5.1 \mathrm{dS} \mathrm{m}^{-1}$ in the irrigation water (MAAS; HOFFMAN, 1977). Although considered tolerant to salt stress, the cotton crop may suffer reductions in growth and production in conditions of high salinity, as reported by Siqueira et al. (2005) and Santos et al. (2016). However, the intensity with which the salt stress inhibits the cotton crop, depends on other factors, such as species, cultivar, types of salts, duration of the stress, crop and irrigation managements, edaphoclimatic conditions and fertilization (MUNNS; TESTER, 2008).

One alternative used to mitigate the deleterious effects caused by water and/or soil salinity on plants is the nutritional supply of nitrogen (N). This macronutrient is among the essential nutrients required by plants because it has a structural function and participates in various organic compounds that are vital for the plant, such as amino acids, proteins, nucleic acids, chlorophyll pigments and proline, among other organic assimilates
(CHAVES et al., 2011). These compounds increase the osmotic adjustment capacity of the plants to salinity and increase the tolerance of the crops to salt stress (SILVA et al., 2008).

In this context, this study aimed to evaluate the growth, water consumption, water use efficiency and production of the colored fiber cotton $\mathrm{cv}$. 'BRS Rubi' as a function of water salinity and $\mathrm{N}$ doses (ND) in the soil.

\section{MATERIAL AND METHODS}

The experiment was carried out in drainage lysimeters under greenhouse conditions, from March to July 2016, at the Center for Technology and Natural Resources of the Federal University of Campina Grande (CTRN/UFCG), Campina Grande,

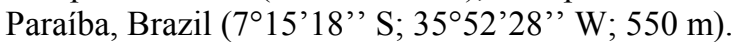

The experimental design was completely randomized blocks, with three replicates, in a $5 \times 5$ factorial scheme, consisting of five irrigation water salinity (ECw) levels $(5.1,6.1,7.1,8.1$ and 9.1 $\left.\mathrm{dS} \mathrm{m}^{-1}\right)$ and five ND $(65,100,135,170$ and $205 \mathrm{mg}$ $\mathrm{N} \mathrm{kg}^{-1}$ soil). The $\mathrm{N}$ fertilization level of $100 \mathrm{mg} \mathrm{N} \mathrm{kg}$ -1 soil for pot experiments, was based on the recommendations of Novais, Neves and Barros (1991).

The experiment used 20 -L plastic pots $(31 \mathrm{~cm}$ top diameter $\times 20 \mathrm{~cm}$ bottom diameter $\times 35 \mathrm{~cm}$ height), with a 4-mm-diameter drain at the bottom, to allow drainage. The tip of the drain inside the lysimeter was involved in a nonwoven geotextile (Bidim OP 30) to avoid obstruction by soil material and the other tip was placed in a plastic bottle to collect the drained water and estimate plant water consumption. The bottom of the lysimeters received a $0.5-\mathrm{kg}$ crushed stone layer, followed by $26 \mathrm{~kg}$ eutrophic Regolithic Neosol, of a sandy loam texture, collected from the $0-30 \mathrm{~cm}$ layer (A horizon) in the municipality of Esperança, Paraíba. Before the experiment, the chemical, physical and hydraulic characteristics of the soil were determined (Table 1), according to the methodologies cited by Donagema et al. (2011).

The cotton cv. 'BRS Rubi' was selected for the experiment because it is a genetic material indicated for cultivation in the semi-arid region of Northeast Brazil. It is a cultivar with dark brown or reddish-brown fiber. The plant reaches a mean height of $1.10 \mathrm{~m}$ and has a $120-140$-day cycle. Its potential yield is between 1,539-1,894 $\mathrm{kg} \mathrm{ha}^{-1}$, under a rainfed regime, in the Northeast region, achieving more than $3,500 \mathrm{~kg} \mathrm{ha}{ }^{-1}$ in irrigated cultivation in some environments (EMBRAPA, 2011). 
G. S. LIMA et al.

Table 1. Chemical and physical characteristics of the eutrophic Regolithic Neosol used in the experiment, before applying the treatments.

\begin{tabular}{|c|c|c|c|c|c|c|c|c|c|}
\hline \multicolumn{10}{|c|}{ Chemical characteristics } \\
\hline \multirow[t]{2}{*}{$\mathrm{pH}_{\mathrm{sp}}$} & \multirow{2}{*}{$\begin{array}{c}\text { O.M. } \\
\text { dag kg }{ }^{-1}\end{array}$} & \multirow{2}{*}{$\begin{array}{c}\mathrm{P} \\
\left(\mathrm{mg} \mathrm{kg}^{-1}\right)\end{array}$} & $\mathrm{K}^{+}$ & $\mathrm{Na}^{+}$ & $\mathrm{Ca}^{2+}$ & $\mathrm{Mg}^{2+}$ & $\mathrm{Al}^{3+}+\mathrm{H}^{+}$ & \multirow{2}{*}{$\begin{array}{l}\text { ESP } \\
(\%)\end{array}$} & \multirow{2}{*}{$\begin{array}{c}\text { ECse } \\
\left(\mathrm{dS} \mathrm{m}^{-1}\right)\end{array}$} \\
\hline & & & ......... & ........... & \multicolumn{3}{|c|}{$\ldots\left(\mathrm{cmol}_{\mathrm{c}} \mathrm{kg}^{-1}\right) \ldots$} & & \\
\hline 5.63 & 1.83 & 18.2 & 0.21 & 0.17 & 3.49 & 2.99 & 5.81 & 1.34 & 0.61 \\
\hline \multicolumn{10}{|c|}{ Physical characteristics } \\
\hline \multicolumn{3}{|c|}{ Particle size fraction $\left(\mathrm{g} \mathrm{kg}^{-1}\right)$} & \multirow{2}{*}{$\begin{array}{c}\text { Textural } \\
\text { class }\end{array}$} & \multicolumn{2}{|c|}{ Water content $(\mathrm{kPa})$} & \multirow[t]{2}{*}{ AW } & \multirow{2}{*}{$\begin{array}{c}\text { Total } \\
\text { porosity } \\
\mathrm{m}^{3} \mathrm{~m}^{-3}\end{array}$} & DA & DP \\
\hline Sand & Silt & Clay & & 33.42 & $\begin{array}{l}1519.5 \\
\text { dag kg }\end{array}$ & & & \multicolumn{2}{|c|}{$\left(\mathrm{kg} \mathrm{dm}^{-3}\right)$} \\
\hline$\overline{572.3}$ & 100.8 & 326.9 & $\mathrm{CL}$ & 12.68 & 4.98 & 7.70 & 0.57 & 1.13 & 2.65 \\
\hline
\end{tabular}

$\mathrm{pH}_{\mathrm{SP}}-\mathrm{pH}$ of the saturation paste; $\mathrm{OM}$ - organic matter (determined by the Walkley-Black wet digestion method); $\mathrm{Ca}^{2+}$ and $\mathrm{Mg}^{2+}$ extracted with $1 \mathrm{~mol} \mathrm{~L}{ }^{-1} \mathrm{KCl}, \mathrm{pH} 7.0 ; \mathrm{Na}^{+}$and $\mathrm{K}^{+}$extracted using $1 \mathrm{~mol} \mathrm{~L}^{-1} \mathrm{NH}_{4} \mathrm{OAc}, \mathrm{pH} 7.0 ; \mathrm{Al} 3++\mathrm{H}+$ extracted by 1 mol L-1 CaOAc, pH 7.0; ESP - exchangeable sodium percentage; ECse - electrical conductivity of the saturation extract; CL - clay loam; AW - available water; DA- apparent density; DP - particle density; ${ }^{*} 33.42 \mathrm{kPa}$ - field capacity, $1519.5 \mathrm{kPa}$ - permanent wilting point.

The five levels of irrigation water salinity were prepared by dissolving $\mathrm{NaCl}, \mathrm{CaCl}_{2} \cdot 2 \mathrm{H}_{2} \mathrm{O}$ and $\mathrm{MgCl}_{2} \cdot 6 \mathrm{H}_{2} \mathrm{O}$, at a $7: 2: 1$ equivalent ratio of $\mathrm{Na}^{+}: \mathrm{Ca}^{2+}$ : $\mathrm{Mg}^{2+}$, in the public supply water in the municipality of Campina Grande, Paraíba $\left[\mathrm{ECW}=1.86 \mathrm{dS} \mathrm{m}^{-1}\right.$ and sodium absorption ratio $\left.(\mathrm{SAR})=\left(7.8 \mathrm{mmol} \mathrm{L}^{-1}\right)^{0.5}\right]$, considering the relationship between the $\mathrm{ECW}$ and the salt concentration $\left(\mathrm{mmol}_{\mathrm{c}} \mathrm{L}^{-1}=10^{*} \mathrm{ECW}\right.$ in $\left.\mathrm{dS} \mathrm{m}^{-1}\right)$, according to Richards (1954).

Before sowing, the soil water content was elevated to field capacity, using the respective saline water of each treatment. After sowing, irrigation was performed daily, by applying in each lysimeter a water volume sufficient to maintain the soil moisture close to field capacity. The applied volume was determined according to the water requirement of the plants, which was estimated through the water balance as the applied water volume minus the volume drained in the previous irrigation.

Eight seeds of the cotton cv. 'BRS Rubi' were equidistantly planted in each lysimeter, at $1.5 \mathrm{~cm}$ depth. At 15 and 25 days after sowing (DAS), thinnings were performed, leaving only the most vigorous plant in each lysimeter.

The fertilizations with phosphorus (300 mg $\mathrm{P}_{2} \mathrm{O}_{5} \quad \mathrm{~kg}^{-1}$ soil) and potassium (150 mg $\mathrm{K}_{2} \mathrm{O} \quad \mathrm{kg}^{-1}$ soil) were based on the recommendations of Novais, Neves and Barros

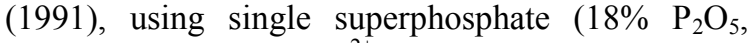
$\left.10-12 \% \mathrm{~S}, 18-20 \% \mathrm{Ca}^{2+}\right)$ and potassium chloride $\left(60 \% \mathrm{~K}_{2} \mathrm{O}\right)$. Phosphorus was supplied in a single application, during the preparation of the lysimeters and potassium was applied as a top-dressing, split into three equal applications at 12, 28 and 42 DAS. Nitrogen fertilization consisted application of urea $(44 \% \mathrm{~N})$, supplied in four applications of $25 \%$ of each pre-established dose, at 15, 30, 45 and 60 DAS.

The micronutrients were supplied via foliar application, at 25, 40 and 55 DAS, by applying
$3 \mathrm{~L}$ of solution containing $2.5 \mathrm{~g} \mathrm{~L}^{-1}$ of Ubyfol [(N (15\%); $\mathrm{P}_{2} \mathrm{O}_{5}$ (15\%); $\mathrm{K}_{2} \mathrm{O}$ (15\%); $\mathrm{Ca}(1 \%) ; \mathrm{Mg}$ (1.4\%); S (2.7\%); Zn (0.5\%); B (0.05\%); Fe (0.5\%); Mn (0.05\%); Cu (0.5\%); Mo (0.02\%)]. The phytosanitary control was preventively performed using neonicotinoid insecticides, triazole fungicide and the synthetic acaricide abamectin, which are specific to the crop.

The effects of ECW and the ND on the cotton cv. 'BRS Rubi' were evaluated in terms of stem diameter (SD), plant height (PH) and leaf area (LA) at $50 \mathrm{DAS}$, and shoot and root dry phytomass (ShDP) and RDP, total dry phytomass (TDP), root: shoot ratio $(\mathrm{R} / \mathrm{S})$, total weight of seeds (TWS), lint weight $(\mathrm{LW})$, harvest index $(\mathrm{HI})$, water consumption (WC) and water use efficiency (WUE), at 130 DAS. $\mathrm{PH}$ was measured as the distance from the base of the plant to the insertion of the apical meristem. The $\mathrm{SD}$ was measured at $5 \mathrm{~cm}$ from the plant base. The LA was estimated by measuring the midrib length of all leaves of the plants, considering the method described by Grimes and Carter (1969), according to Eq. 1:

$$
\mathrm{y}=\Sigma 0.4322 x \mathrm{P}^{2.3002}
$$

where:

$\mathrm{y}$ - total leaf area of the plant $\left(\mathrm{cm}^{2}\right)$,

$\mathrm{P}$ - the midrib length of the leaf $(\mathrm{cm})$ and the leaf area per plant were determined by the sum of the areas of all leaves.

For the quantification of the dry phytomass (ShDP and TDP), the plants were collected, separated into stem, leaves and roots, placed in paper bags and dried in an oven at temperature of $65^{\circ} \mathrm{C}$, until constant weight, to obtain the dry phytomass of shoots (LDP+StDP), leaves and stems and total dry phytomass adding the root dry phytomass (LDP+StDP+RDP). The root/shoot ratio was obtained by the coefficient between root dry phytomass and shoot dry phytomass.

The bolls were manually harvested when $90 \%$ 
were open. The TWS and LW were determined after removing the seeds, using a scale with $0.01 \mathrm{~g}$ resolution. Plant WC was determined through the sum of the applied water volume minus the volume drained during the cycle. WUE was estimated using the relation between the total dry matter and the water volume effectively consumed by the plants of each treatment, according to Sartori et al. (2013).

The obtained data were evaluated using analysis of variance by $F$ test at 0.05 and 0.01 probability levels. Significant differences were analyzed by linear and quadratic polynomial regression, using the statistical program SISVAR-ESAL (FERREIRA, 2011).

\section{RESULTS AND DISCUSSION}

According to the summary of the analysis of variance (Table 2), the interaction between the factors $\mathrm{ECw} \times \mathrm{ND}$ and the ND did not cause a significant effect $(p>0.05)$ on any analyzed variable of the cotton crop. However, the saline levels of the irrigation water significantly interfered $(p<0.01)$ with SD, PH, LA, ShDP, TDP and R/S of the 'BRS Rubi' cotton. Santos et al. (2016) evaluated the morphophysiology and production of colored cotton 'BRS Topázio', irrigated with various water salinity levels (ECw: 0.7-8.7 $\mathrm{dS} \mathrm{m}^{-1}$ ) and fertilized with $40-120 \mathrm{mg} \mathrm{N} \mathrm{kg}^{-1}$ soil. These authors also observed a significant effect of the saline levels for all growth variables evaluated.

Table 2. Summary of the analysis of variance for stem diameter (SD), plant height (PH), leaf area (LA), shoot dry phytomass (ShDP), total dry phytomass (TDP) and root: shoot ratio (R/S) of 'BRS Rubi' cotton irrigated with various water salinity levels and nitrogen doses.

\begin{tabular}{|c|c|c|c|c|c|c|c|}
\hline \multirow{2}{*}{ Source of variation } & \multirow{2}{*}{ DF } & \multicolumn{6}{|c|}{ Mean squares } \\
\hline & & SD & PH & LA & ShDP & TDP & $\mathrm{R} / \mathrm{S}$ \\
\hline Saline levels (ECw) & 4 & $3.98^{* *}$ & $263.94^{* *}$ & $1218106.82^{* *}$ & $221.51^{* *}$ & $254.13^{* *}$ & $0.0267^{* *}$ \\
\hline Linear regression & 1 & $15.16^{* *}$ & $985.18^{* *}$ & $4589331.28^{* *}$ & $796.90^{* *}$ & $921.79^{* *}$ & $0.0982^{* *}$ \\
\hline Quadratic regression & 1 & $0.22^{\mathrm{ns}}$ & $33.17^{\mathrm{ns}}$ & $89007.03^{\text {ns }}$ & $54.47^{* *}$ & $55.18^{* *}$ & $0.0011^{\mathrm{ns}}$ \\
\hline $\mathrm{N}$ doses $(\mathrm{ND})$ & 4 & $0.07^{\mathrm{ns}}$ & $2.07^{\mathrm{ns}}$ & $25190.49^{\mathrm{ns}}$ & $3.54^{\mathrm{ns}}$ & $5.41^{\mathrm{ns}}$ & $0.0025^{\mathrm{ns}}$ \\
\hline Linear regression & 1 & $0.17^{\mathrm{ns}}$ & $0.17^{\mathrm{ns}}$ & $13857.42^{\mathrm{ns}}$ & $7.75^{\mathrm{ns}}$ & $13.82^{*}$ & $0.0005^{\mathrm{ns}}$ \\
\hline Quadratic regression & 1 & $0.02^{\mathrm{ns}}$ & $0.09^{\mathrm{ns}}$ & $48264.58^{\mathrm{ns}}$ & $0.004^{\mathrm{ns}}$ & $0.47^{\mathrm{ns}}$ & $0.0084^{\mathrm{ns}}$ \\
\hline Interaction (ECw x ND) & 15 & $0.10^{\mathrm{ns}}$ & $7.37^{\mathrm{ns}}$ & $40551.68^{\mathrm{ns}}$ & $3.11^{\mathrm{ns}}$ & $4.26^{\mathrm{ns}}$ & $0.0014^{\mathrm{ns}}$ \\
\hline Blocks & 2 & $0.15^{\mathrm{ns}}$ & $23.16^{\mathrm{ns}}$ & $47702.71^{\mathrm{ns}}$ & $2.68^{\mathrm{ns}}$ & $2.29^{\mathrm{ns}}$ & $0.0027^{\mathrm{ns}}$ \\
\hline Residual & 48 & 0.11 & 8.61 & 33012.00 & 2.11 & 2.77 & 0.0016 \\
\hline $\mathrm{CV}(\%)$ & & 9.01 & 12.95 & 14.74 & 20.43 & 20.45 & 24.77 \\
\hline
\end{tabular}

$\mathrm{ns}, * *, *$ respectively, not significant, significant at $\mathrm{p}<0.01$ and $\mathrm{p}<0.05$.

The SD of 'BRS Rubi' cotton was linearly reduced by the increased saline levels of the irrigation water (Figure 1A), with a $5.28 \%$ decrease per unit increase in ECw. This corresponded to a $21.14 \%$ decrease in SD for plants irrigated with $9.1 \mathrm{dS} \mathrm{m}^{-1}$ compared to the lowest water salinity level $\left(5.1 \mathrm{dS} \mathrm{m}^{-1}\right)$. The inhibition in cotton SD due to the $\mathrm{ECw}$ levels can be attributed to the decrease in the water potential of the soil solution, caused by the excess soluble salts in the root zone, with negative responses on cell turgor and expansion, reducing plant growth (KHALID; SILVA, 2010). Siqueira et al. (2005) evaluated the growth of the colored fiber cotton cv. 'CNPA 2002/26' under saline water irrigation ranging from 2.0-9.5 dS $\mathrm{m}^{-1}$. In concurrence with the current study, an increase in $\mathrm{ECW}$ levels led to a linear decrease in SD, reporting a $23.81 \%$ decrease in the SD of plants irrigated with $9.5 \mathrm{dS} \mathrm{m}^{-1}$ compared to those that received the water of $2.0 \mathrm{dS} \mathrm{m}^{-1}$.

As observed for the SD (Figure 1A), PH was also negatively affected by the increase in water salinity. According to the regression equation (Figure 1B), the PH decreased $6.29 \%$ per unit increase in the ECw. Based on the results (Figure 1B), plants irrigated with water of $9.1 \mathrm{dS} \mathrm{m}^{-1}$ showed a $10.33 \mathrm{~cm}$ $(25.17 \%)$ decrease in height compared to those irrigated with an ECw of $5.1 \mathrm{dS} \mathrm{m}^{-1}$. This situation, in general, results from the high concentrations of salts dissolved in the soil solution, which decreases the osmotic potential of the solution, limiting the availability of water to the plants. Consequently, the water flow in the soil-plant-atmosphere direction decreases, inhibiting plant growth (COELHO et al., 2013). Similar results were found by Jácome et al. (2003), evaluating the effects of irrigation water salinity $\left(2.0-10 \mathrm{dS} \mathrm{m}^{-1}\right)$ on the growth of cotton genotypes ('CNPA Precoce 1', 'CNPA Precoce 2', 'CNPA 7H', 'CNPA Acala93/15' and 'Embrapa 113-Algodão 7MH'). These authors observed that the cotton growth in height was significantly inhibited with the increase in $\mathrm{ECw}$, regardless of the studied genotype. 

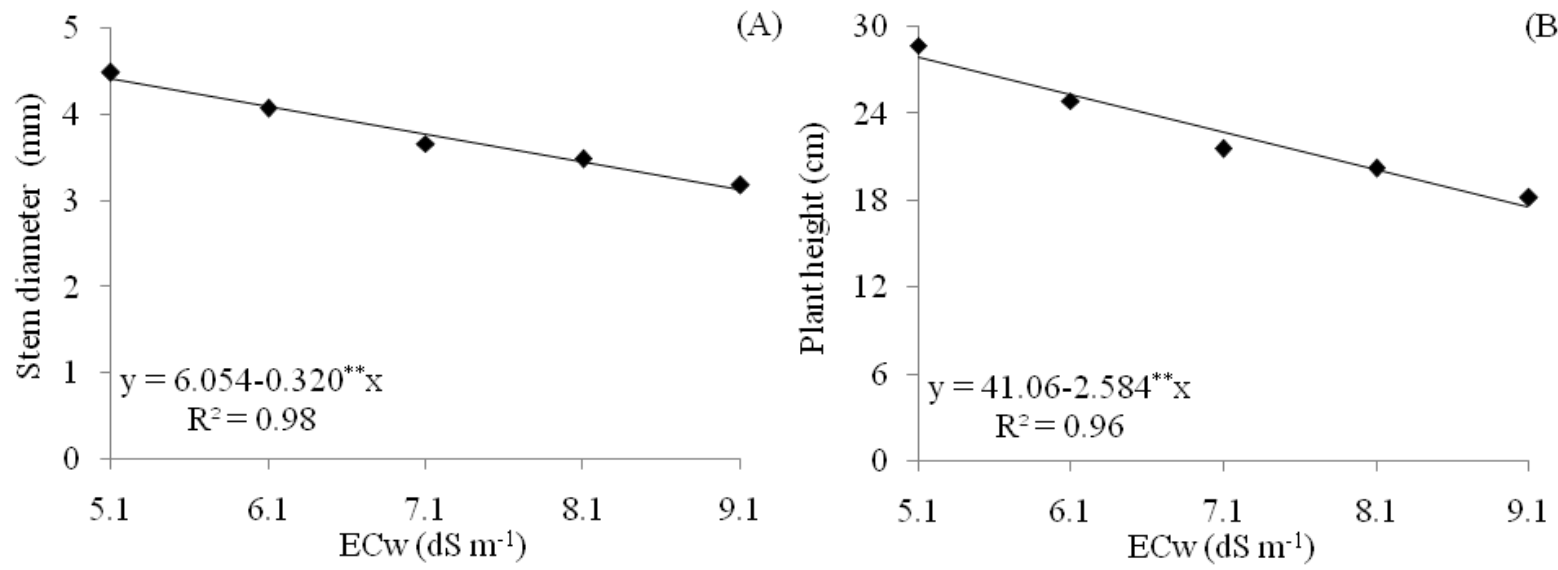

Figure 1. Stem diameter (A) and plant height (B) of the cotton cv. 'BRS Rubi' as a function of the electrical conductivity of the water - ECw.

The increase in irrigation water salinity caused a significant decrease in the LA of the cotton cv. 'BRS Rubi' (Figure 2A), showing a linear decrease of $9.90 \%$ per unit increase in $\mathrm{ECW}$. Comparatively, the LA of plants irrigated with the lowest water salinity level $\left(5.1 \mathrm{dS} \mathrm{m}^{-1}\right)$ was $705.48 \mathrm{~cm}^{2}(417.92 \%)$ higher than those irrigated with the highest water salinity $\left(9.1 \mathrm{dS} \mathrm{m}^{-1}\right)$. Under salt stress conditions, the reduction in LA typically results from the decrease in the cell volume, through the loss of turgor because cell elongation and division depend directly on the process of cell wall

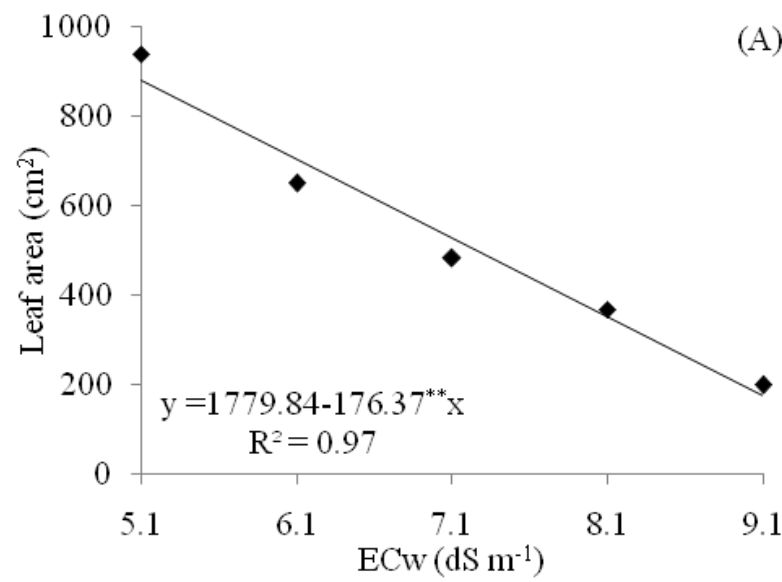

extensibility (MUNNS; TESTER, 2008). The decrease in LA is generally considered an important strategy to protect the plants from, and/or acclimate the plants to, the high salinity, ultimately, minimizing the water losses through transpiration and maintaining a high cell water potential (NASCIMENTO et al., 2011). Evaluating the 'BRS Rubi' cotton at different ECw levels (0.7-8.7 dS m $\left.{ }^{-1}\right)$ under greenhouse conditions, Santos et al. (2016) also concluded that LA was the variable most affected by the increase in the irrigation water salinity.

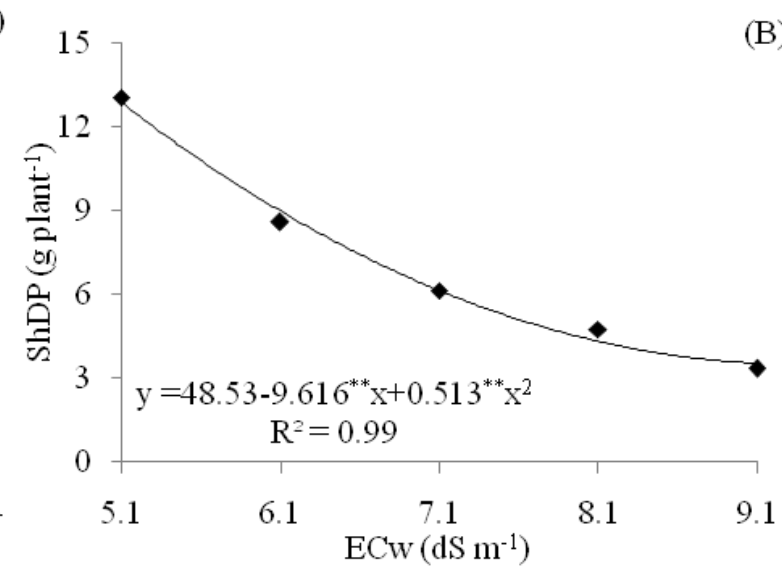

Figure 2. Leaf area (A) and shoot dry phytomass-ShDP (B) of the cotton cv. 'BRS Rubi' as a function of the electrical conductivity of the water - ECw.

Cotton ShDP decreased with the increase in the $\mathrm{ECw}$ (Figure 2B). Based on the regression equation, the effect of salt stress on ShDP was more expressive in plants irrigated with the highest $\mathrm{ECW}$ levels, such that the lowest phytomass accumulation was obtained in plants irrigated with $\mathrm{ECw}$ of $9.1 \mathrm{dS} \mathrm{m}^{-1}$ (3.50 $\left.\mathrm{g} \mathrm{plant}^{-1}\right)$. In contrast, the highest phytomass accumulation occurred in plants irrigated with water of $5.1 \mathrm{dS} \mathrm{m}^{-1}\left(12.83 \mathrm{~g} \mathrm{plant}^{-1}\right)$. The ShDP was reduced by $9.33 \mathrm{~g} \mathrm{plant}^{-1}$, when irrigated with the highest $\left(9.1 \mathrm{dS} \mathrm{m}^{-1}\right)$ compared to lowest $\left(5.1 \mathrm{dS} \mathrm{m}^{-1}\right)$ salinity level, which corresponded to a relative decrease of $74.40 \%$. The reduction in ShDP production, in general, is a response to the limitations in the photosynthetic capacity due to the excess salts in the root zone (CAIXETA et al., 2010), with degenerative effects on LA and other evaluated growth variables. A similar behavior was reported by Lima et al. (2014), who evaluated the growth of 'BRS Energia' castor bean irrigated with waters of ECW from 0.4-4.4 $\mathrm{dS} \mathrm{m}^{-1}$ and observed a negative influence of the ECw levels, with a $55.32 \%$ decrease 
(from 57.21 to $25.56 \mathrm{~g} \mathrm{plant}^{-1}$ ) in the ShDP of plants irrigated with water with the highest concentration of salts.

The increase in water salinity, as for the other variables, also decreased the TDP of the cotton cv. 'BRS Rubi', as shown in Figure 3A, and, according to the regression equation, the data fitted to a quadratic model. There was a reduction from 14.20 to $4.16 \mathrm{~g} \mathrm{plant}^{-1}$ in TDP as the water salinity levels increased, i.e., a $75.32 \%$ decrease in the TDP of plants irrigated with ECw of 9.1 versus $5.1 \mathrm{dS} \mathrm{m}^{-1}$. The decreased TDP in cotton plants cultivated under high salinity conditions can be a consequence of the high metabolic consumption of energy involved in the synthesis of the osmotically active organic compounds. Energy is necessary for the processes of compartmentalization and regulation in the transport of ions, associated with the adaptation to salt stress and reduction in carbon production (MENDONÇA et al., 2007).
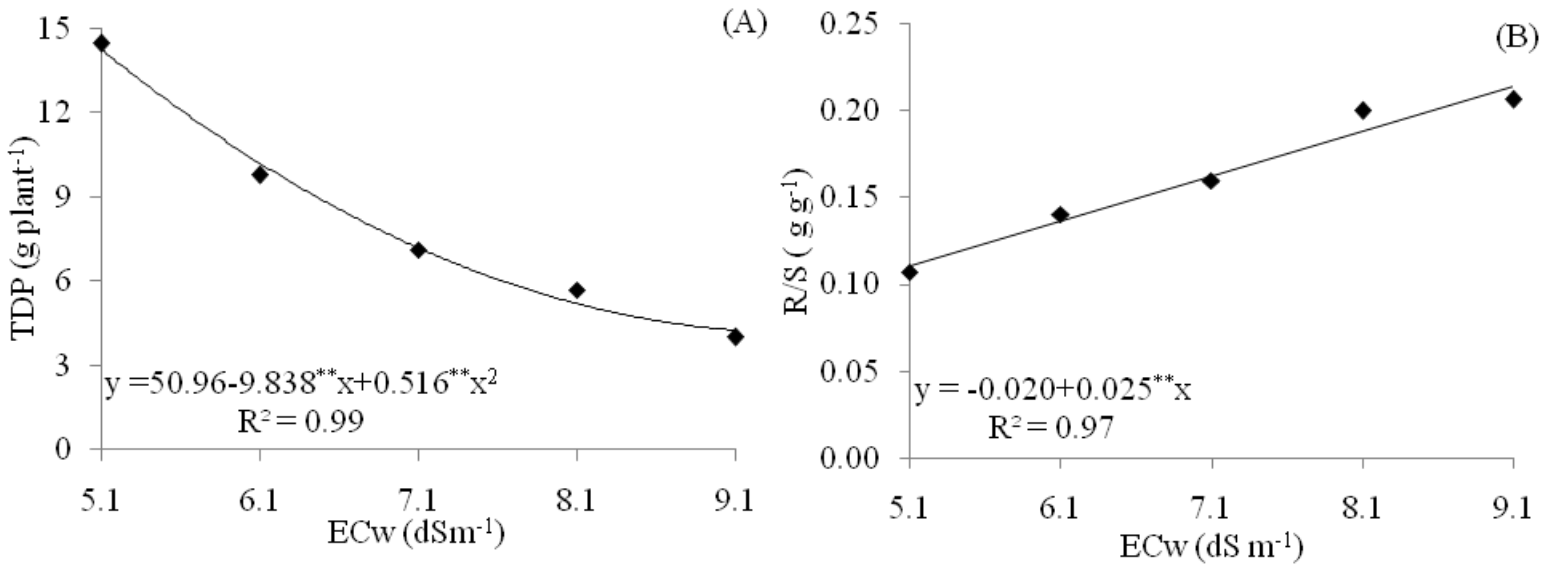

Figure 3. Total dry phytomass - TDP (A) and root/shoot ratio - R/S (B) of the cotton cv. 'BRS Rubi', as a function of the electrical conductivity of the water - ECw.

The $\mathrm{R} / \mathrm{S}$ is a physiological parameter that refers to the level of contribution by the root system reserves in stimulating shoot growth (SOARES et al., 2013). The regression equation in Figure 3B shows the cotton R/S increased linearly by $12.5 \%$ per unit increase in ECw. Thus, the RDP was less inhibited by the salinity relative to the shoots. Cotton plants irrigated with water of $5.1 \mathrm{dS} \mathrm{m}^{-1}$ showed a reduction of $0.10 \mathrm{~g} \mathrm{~g}^{-1}$ in $\mathrm{R} / \mathrm{S}$, compared to those subjected to $\mathrm{ECW}$ of $9.1 \mathrm{dS} \mathrm{\textrm {m } ^ { - 1 }}$. The greater phytomass allocation in the root system of the cotton cv. 'BRS Rubi', as observed in the R/S (Figure 3B), can be considered an adaptive characteristic of the plants exposed to environments with high concentrations of salts. This prioritizes water absorption and minimizes water loss through leaf transpiration because the allocation of phytomass in the leaves is reduced (SUASSUNA et al., 2012). Soares et al. (2013), in a study evaluating the physiology and phytomass accumulation of castor bean, cv. 'BRS Energia', irrigated with ECw levels ranging from 0.3-3.9 $\mathrm{dS} \mathrm{m} \mathrm{m}^{-1}$, also observed an $\mathrm{R} / \mathrm{S}$ increase, with a maximum value of $0.42 \mathrm{~g} \mathrm{~g}^{-1}$ at the highest ECw level $\left(3.9 \mathrm{dS} \mathrm{m}^{-1}\right)$.

According to the summary of the analysis of variance (Table 3 ), there was a significant effect $(p<0.05)$ of the interaction between the $\mathrm{ECw} \times \mathrm{ND}$ factors on TWS and LW. The ND did not significantly influence $(p>0.05)$ any of the studied variables. In contrast, the irrigation water salinity levels significantly influenced $(p<0.01)$ the TWS, LW, WC, WUE and, at $\mathrm{p}<0.05$, the HI of the cotton crop.

Figure 4A reveals that increasing the ND linearly inhibited the TWS of the cotton plants (7.14, 7.85 and $7.38 \%$ decrease per unit increase in $\mathrm{ECw}$ for 100,135 and $170 \mathrm{mg} \mathrm{N} \mathrm{kg}{ }^{-1}$ soil, respectively), which corresponded to the respective decreases of $1.88,1.37$ and $0.81 \mathrm{~g} \mathrm{plant}^{-1}$ in the TWS of plants irrigated with $\mathrm{ECW}$ of 9.1 versus $5.1 \mathrm{dS} \mathrm{m}^{-1}$. Conversely, the TWS of cotton plants fertilized with 65 and $205 \mathrm{mg} \mathrm{N} \mathrm{kg}^{-1}$ soil showed the best fit to the quadratic model and the highest values for this variable $\left(6.57\right.$ and $\left.1.09 \mathrm{~g} \mathrm{plant}^{-1}\right)$ were observed when plants were irrigated with $\mathrm{ECW}$ of 7.6 and $5.1 \mathrm{dS} \mathrm{m}^{-1}$, respectively.

Additionally, according to the regression equations (Figure 4A), the TWS substantially decreased with the increase in ND, and the highest deleterious effect occurred in plants cultivated under $\mathrm{ECW}$ of $9.1 \mathrm{dS} \mathrm{m}^{-1}$ and $205 \mathrm{mg} \mathrm{N} \mathrm{kg}^{-1}$ soil. Thus, the reduction in the TWS of the cotton cv. 'BRS Rubi' occurred possibly because the high concentration of salts in the soil solution promoted an antagonistic effect on the absorption of essential nutrients, particularly $\mathrm{NO}_{3}^{-}, \mathrm{K}^{+}$and $\mathrm{Ca}^{2+}$, due to the excess of $\mathrm{Na}^{+}$and $\mathrm{Cl}^{-}$present in the soil solution (FERREIRA NETO et al., 2007). 
Table 3. Summary of the analysis of variance for the total weight of seeds (TWS), lint weight (LW), harvest index (HI), water consumption (WC) and water use efficiency (WUE) of the cotton cv. 'BRS Rubi', irrigated with water of different salinity levels and nitrogen doses.

\begin{tabular}{lrccccc}
\hline \multirow{2}{*}{ Source of variation } & \multirow{2}{*}{ DF } & \multicolumn{5}{c}{ Mean squares } \\
\cline { 3 - 7 } & & TWS & LW & HI & WC & WUE \\
\hline Saline levels (ECw) & 4 & $44.62^{* *}$ & $20.78^{* *}$ & $0.018^{*}$ & $65.51^{* *}$ & $0.125^{* *}$ \\
Linear regression & 1 & $158.85^{* *}$ & $166.99^{* *}$ & $0.069^{*}$ & $179.69^{* *}$ & $0.478^{* *}$ \\
Quadratic regression & 1 & $13.19^{*}$ & $13.43^{*}$ & $0.0002^{\mathrm{ns}}$ & $6.36^{\mathrm{ns}}$ & $0.006^{\mathrm{ns}}$ \\
N doses (ND) & 4 & $0.16^{\mathrm{ns}}$ & $0.55^{\mathrm{ns}}$ & $0.005^{\mathrm{ns}}$ & $0.32^{\mathrm{ns}}$ & $0.004^{\mathrm{ns}}$ \\
Linear regression & 1 & $0.01^{\mathrm{ns}}$ & $0.10^{\mathrm{ns}}$ & $0.0001^{\mathrm{ns}}$ & $0.02^{\mathrm{ns}}$ & $0.011^{\mathrm{ns}}$ \\
Quadratic regression & 1 & $0.58^{\mathrm{ns}}$ & $1.61^{\mathrm{ns}}$ & $0.004^{\mathrm{ns}}$ & $0.10^{\mathrm{ns}}$ & $0.0009^{\mathrm{ns}}$ \\
Interaction (ECW x ND) & 15 & $2.77^{*}$ & $1.64^{*}$ & $0.017^{\mathrm{ns}}$ & $7.86^{\mathrm{ns}}$ & $0.005^{\mathrm{ns}}$ \\
Blocks & 2 & $0.21^{\mathrm{ns}}$ & $0.20^{\mathrm{ns}}$ & $0.003^{\mathrm{ns}}$ & $2.43^{\mathrm{ns}}$ & $0.002^{\mathrm{ns}}$ \\
Residual & 48 & 0.98 & 0.44 & 0.006 & 35.51 & 0.004 \\
\hline CV (\%) & & 19.38 & 17.43 & 18.00 & 2.78 & 21.85 \\
\hline
\end{tabular}

$\mathrm{ns}, * *$, * respectively, not significant, significant at $\mathrm{p}<0.01$ and $\mathrm{p}<0.05$.

The interaction between the factors $\mathrm{ECW} \times \mathrm{ND}$ also promoted a significant effect on the LW. Based on the regression equation, the data corresponding to 65,170 and $205 \mathrm{mg} \mathrm{N} \mathrm{kg}^{-1}$ soil fitted to a quadratic model, and the highest LW values $\left(4.73,1.15,0.78 \mathrm{~g} \mathrm{plant}^{-1}\right)$ were obtained in plants irrigated with ECw of 7.5, 7.1 and $6.7 \mathrm{dS} \mathrm{m}^{-1}$, respectively. Conversely, the minimum LW values were observed when plants were irrigated with $\mathrm{ECW}$ of $9.1 \mathrm{dS} \mathrm{m}^{-1}$ and $205 \mathrm{mg} \mathrm{N} \mathrm{kg}^{-1}$ soil. For cotton plants fertilized with $\mathrm{ND}$ of 100 and $135 \mathrm{mg} \mathrm{kg}^{-1}$
(Figure 4B), there was a negative linear effect on LW, with reductions of about 7.84 and $8.58 \%$, respectively, per unit increase in $\mathrm{ECw}$, i.e., decreases of 1.89 and $1.03 \mathrm{~g} \mathrm{plant}^{-1}$ in the LW of plants irrigation with $\mathrm{ECw}$ of $9.1 \mathrm{dS} \mathrm{m}^{-1}$, compared to an $\mathrm{ECW}$ of $5.1 \mathrm{dS} \mathrm{m}^{-1}$. These results differ from those of Paiva et al. (2016), who studied the fiber quality of the cotton cv. 'BRS Verde', irrigated with waters of increasing salinity (ECw: $0.55-3.53 \mathrm{dS} \mathrm{\textrm {m } ^ { - 1 }}$ ) and observed that LW was not influenced by the increase in the water salinity.

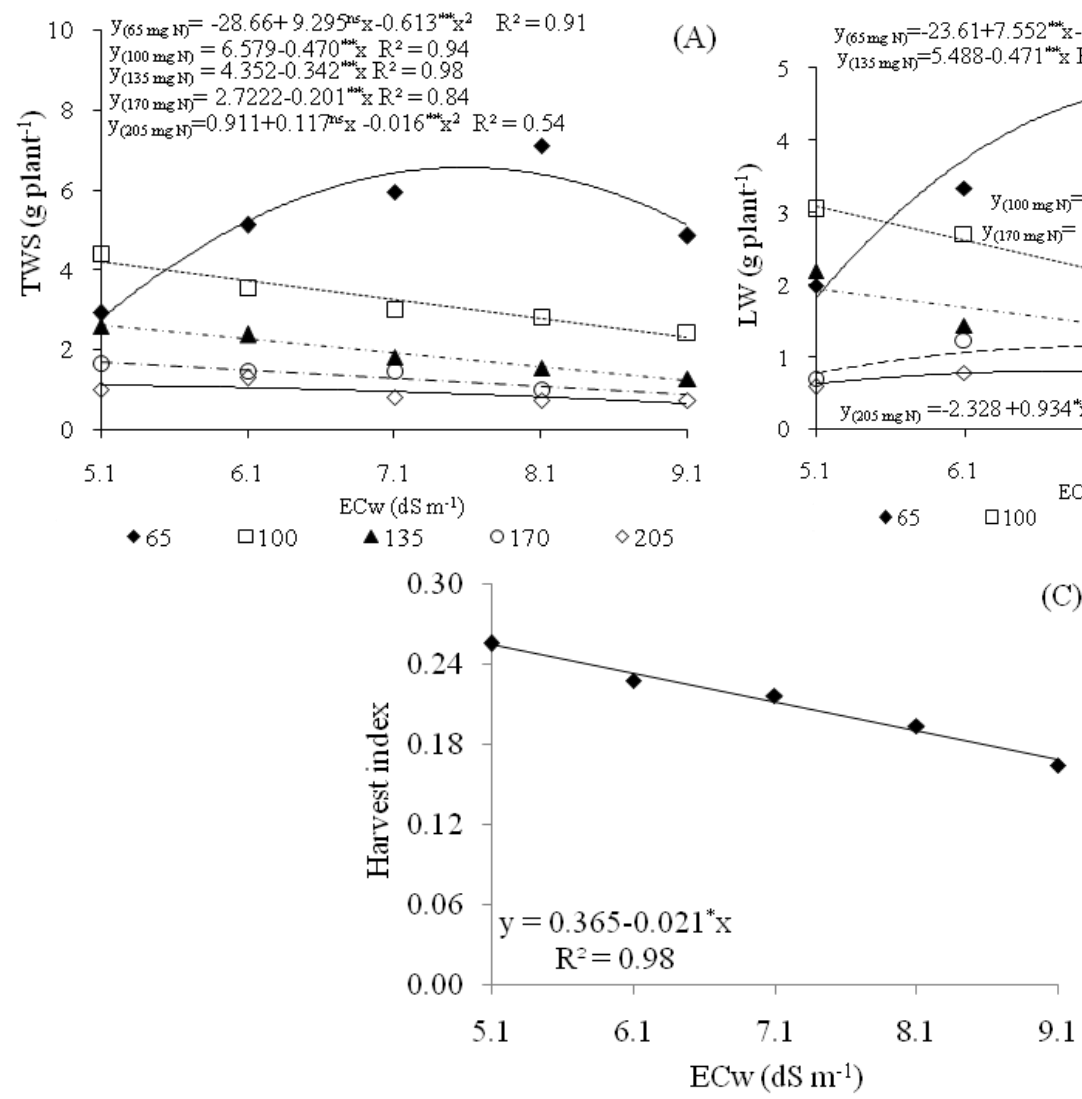

Figure 4. Total weight of seeds - TWS (A), lint weight - LW (B) and harvest index - HI (C) of the cotton cv. 'BRS Rubi', as a function of the interaction between the electrical conductivity of the water - $\mathrm{ECW}$ and nitrogen doses. 
The increase in saline levels of the irrigation water also led to a linear decrease in the HI of the cotton cv. 'BRS Rubi'. According to the estimate obtained from the regression equation (Figure 4C), $\mathrm{HI}$ decreased $5.75 \%$ per unit increase in $\mathrm{ECw}$, i.e., cotton plants irrigated with water of $9.1 \mathrm{dS} \mathrm{\textrm {m } ^ { - 1 }}$ showed a $23.01 \%$ decrease in the $\mathrm{HI}$, relative to those irrigated with the lowest water salinity level $\left(5.1 \mathrm{dS} \mathrm{m}^{-1}\right)$. Thus, the decrease in HI is associated with the reduction in the cotton TDP (Figure 3A) because the increase in the water salinity levels promotes a reduction in the production of photoassimilates, particularly through the excessive absorption of the $\mathrm{Na}^{+}$and $\mathrm{Cl}^{-}$ions. This inhibits leaf expansion (Figure 2A), promoting early senescence and, consequently, reduces the area intended for the photosynthetic process, and thereby, decreasing the lint production of the crop (SOUSA et al., 2010). Nobre et al. (2011), evaluating the production of sunflower cv. 'Embrapa 122/V-2000' irrigated with water of $0.5-4.9 \mathrm{dS} \mathrm{m} \mathrm{m}^{-1}$, concluded that the $\mathrm{HI}$ decreases linearly from the threshold $\mathrm{ECW}$ of $0.5 \mathrm{dS} \mathrm{m}^{-1}$.

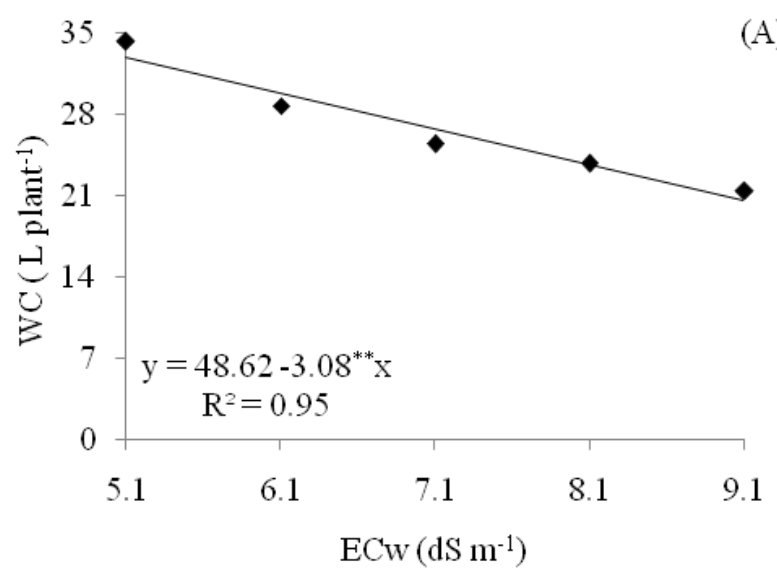

The WC of the cotton cv. 'BRS Rubi' significantly reduced with the increase in $\mathrm{ECW}$ levels. Based on the regression equation (Figure 5A), as the water salinity levels increased, WC linearly decreased, with a reduction of $6.33 \%$ per unit increase in $\mathrm{ECW}$, i.e., cotton plants cultivated under irrigation with water of $9.1 \mathrm{dS} \mathrm{m}^{-1}$ showed a decrease of $37.43 \%\left(12.32 \mathrm{~L} \mathrm{plant}^{-1}\right)$ in $\mathrm{WC}$, compared with those irrigated with $\mathrm{ECW}$ of $5.1 \mathrm{dS} \mathrm{m}^{-1}$. The reduction in WC of the cotton cv. 'BRS Rubi', results from the decrease in the osmotic potential of the soil solution, due to the increment in the concentration of salts in the soil solution. This promotes an increase in the tension necessary for the plant to absorb water from the soil because its water potential becomes more negative. Consequently, the plant will have more difficulty using this water, which is not readily available, despite its presence in the soil (SOUSA et al., 2011). The results also agree with those of Nobre et al. (2014), who reported a reduction in the WC of 'BRS Energia' castor bean as the $\mathrm{ECw}$ increased (from 0.4-4.4 $\mathrm{dS} \mathrm{m} \mathrm{m}^{-1}$ ), with a reduction of $11.31 \%$ per unit increase in $\mathrm{ECw}$.

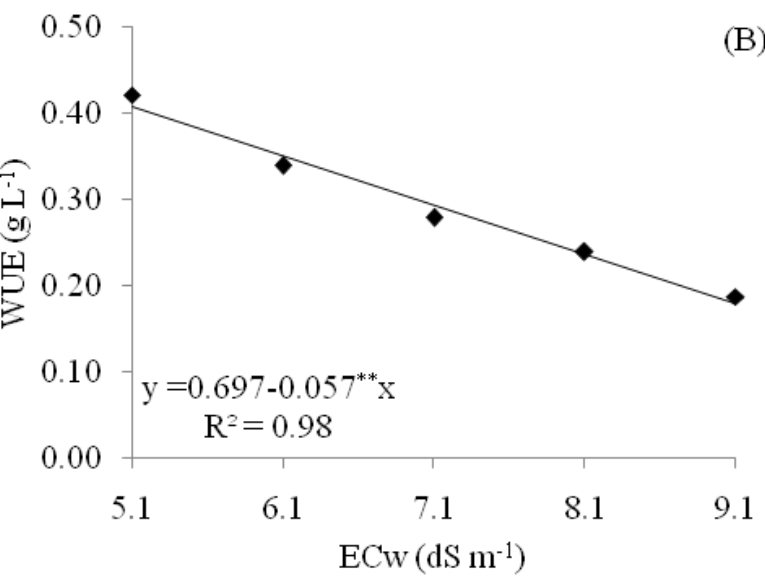

Figure 5. Water consumption - WC (A) and water use efficiency - WUE (B) of the cotton cv. 'BRS Rubi,' as a function of the electrical conductivity of the water - ECw.

The WUE of 'BRS Rubi' cotton was also negatively affected by the increasing $\mathrm{ECW}$. According to the regression equation (Figure 5B), there was a linear reduction of $8.17 \%$ per unit increase in ECW. In addition, the WUE of the cotton plants irrigated with ECw of $9.1 \mathrm{dSm}^{-1}$ was $56.11 \%$ $\left(0.228 \mathrm{~g} \mathrm{~L}^{-1}\right)$ lower than that of plants irrigated with an ECW of $5.1 \mathrm{dS} \mathrm{m}^{-1}$. Thus, based on the WUE data (Figure 5B), it becomes evident that 'BRS Rubi' cotton plants had a lower capacity to convert the effectively consumed water volume into dry phytomass as the saline level of the irrigation water increased. This reduction, in general, occurs because of the decrease in the osmotic and water potentials of the soil solution. These conditions decrease growth, particularly evident in the variables SD, PH, LA, ShDP and TDP and, consequently, reflects in a reduction of WC and WUE. In castor bean cv. 'BRS Energia' plants, Nobre et al. (2014) observed that irrigation with water of increasing salinity levels reduced WUE.

\section{CONCLUSIONS}

Water salinity above $5.1 \mathrm{dS} \mathrm{m} \mathrm{m}^{-1}$ inhibits the growth in stem diameter, plant height and leaf area, shoot and total dry phytomass, water consumption and water use efficiency by the cotton cv. 'BRS Rubi';

The root system of the cotton crop is the organ least damaged by the salt stress, compared with the shoots, and the root/shoot ratio shows a positive linear relationship with the increase in water 
salinity.

Nitrogen fertilization does not mitigate the deleterious effects of salt stress on the growth, production, water consumption and water use efficiency of cotton plants, cv. 'BRS Rubi';

There was significant effect of the interaction between the water salinity levels and nitrogen doses on the total weight of seeds and lint, and the highest values were obtained using water of 7.6 and $7.5 \mathrm{dS} \mathrm{m} \mathrm{m}^{-1}$ and dose of $65 \mathrm{mg} \mathrm{N} \mathrm{kg}{ }^{-1}$ of soil, respectively.

\section{ACKNOWLEDGMENTS}

To the National Program of Post-Doctorate (PNPD/CAPES/UFCG), for granting the scholarship to the first author and to the National Institute of Science and Technology in Salinity - INCTSal, for funding the project.

\section{REFERÊNCIAS}

AYERS, R. S.; WESTCOT, D. W. A qualidade da água na agricultura. 2. ed. Campina Grande, $\mathrm{PB}$ : UFPB. 1999. $153 \mathrm{p}$.

CAIXETA, D. F. et al. Crescimento da plântula de milho à aplicação de inseticidas na semente sob diferentes disponibilidades hídricas. Revista da FZVA, Uruguaiana, v. 17, n. 1, p. 78-87, 2010.

CHAVES, L. H. G. et al. Consumo de água e eficiência do uso para cultivar de mamona Paraguaçu submetida à fertilização nitrogenada. Revista de Engenharia Ambiental, Espírito Santo do Pinhal, v. 8, n. 1, p. 126-133, 2011.

COELHO, J. B. M. et al. Comportamento hídrico e crescimento do feijão vigna cultivado em solos salinizados. Revista Brasileira de Engenharia Agrícola e Ambiental, Campina Grande, v. 17, n. 4, p. 379-385, 2013.

DONAGEMA, G. K. et al. Manual de métodos de análise de solo. 2. ed. Rio de Janeiro, RJ: Embrapa Solos. 2011. 230 p.

ECHER, F. R. et al. Estresse hídrico induzido por manitol em cultivares de algodão. Revista Ciência Agronômica, Fortaleza, v. 41, n. 4, p. 638-645, 2010 .

EMPRESA BRASILEIRA DE PESQUISA AGROPECUÁRIA - EMBRAPA. Algodão Colorido: "Tecnologia Embrapa para a geração de emprego e renda na agricultura familiar do Brasil'. Campina Grande, PB: EMBRAPA, 2011. 2 p.

FERREIRA NETO, M. et al. Emissão foliar, relações iônicas e produção do coqueiro irrigado com água salina. Ciência Rural, Santa Maria, v. 37, n. 6, p. 1675-1681, 2007.

FERREIRA, D. F. Sisvar: A computer statistical analysis system. Ciência e Agrotecnologia, Lavras, v. 35 , n. 6 , p. 1039-1042. 2011.

GRIMES, D. W.; CARTER, L. M. A linear rule for direct non destructive leaf área measurements. Agronomy Journal, Madison, v. 3, n. 61, p. $477-$ $479,1969$.

JÁCOME, A. G. et al. Crescimento de genótipos de algodoeiro em função da salinidade da água de irrigação. Acta Scientiarum. Agronomy, Maringá, v. 25 , n. 2 , p. $305-313,2003$

JERÔNIMO, J. F. et al. Qualidade da semente e fibra de algodão na caracterização do descaroçador de 25 serras. Revista Brasileira de Engenharia Agrícola e Ambiental, Campina Grande, v. 18, n. 6, p. 664 671,2014

KHALID, A.; SILVA, J. A. T. Yield, essential oil and pigment content of Calendula officinalis $\mathrm{L}$. flower heads cultivated under salt stress conditions. Scientia Horticulturae, Amsterdam, v. 126, n. 2, p. 297-305, 2010

KHAN, M. H.; PANDA, S. K. Alterations in root lipid peroxidation and antioxidative responses in two rice cultivars under $\mathrm{NaCl}$-salinity stress. Acta Physiologia e Plantarum, Bangalore, v. 30, n. 1, p. 81-89, 2008.

LIMA, G. S. et al. Crescimento e componentes de produção da mamoneira sob estresse salino e adubação nitrogenada. Engenharia Agrícola, Jaboticabal, v. 34, n. 5, p. 854-866, 2014.

MAAS, E. V.; HOFFMAN, G. H. Crop salt tolerance - Current assessment. Journal of the Irrigation and Drainage Division of ASCE, New York, v. 103, n. 2, p. 115-134, 1977.

MENDONÇA, A. V. R. et al. Características biométricas de mudas de Eucalyptus $s p$ sob estresse salino. Revista Árvore, Viçosa, v. 31, n. 3, p. 365 372,2007

MUNNS, R.; TESTER, M. Mechanism of salinity tolerance. Annual Review of Plant Biology, Palo Alto, v. 59, n. 1, p. 651-681, 2008.

NASCIMENTO, S. P. et al. Tolerância ao déficit hídrico em genótipos de feijão-caupi. Revista 
Brasileira de Engenharia Agrícola e Ambiental, Campina Grande, v. 15, n. 8, p. 853-860, 2011.

NOBRE, R. G. et al. Produção de girassol sob estresse salino e adubação nitrogenada. Revista Brasileira de Ciência do Solo, Viçosa, v. 35, n. 3, p. 929-937, 2011.

NOBRE, R. G. et al. Crescimento, consumo e eficiência do uso da água pela mamoneira sob estresse salino e nitrogênio. Revista Caatinga, Mossoró, v. 27, n. 2, p. 148 -158, 2014.

NOVAIS, R. F.; NEVES, J. C. L.; BARROS, N. F. Ensaio em ambiente controlado. In: OLIVEIRA, A. $\mathrm{J}$. et al. (Eds.). Métodos de pesquisa em fertilidade do solo. Brasília: Embrapa SEA, 1991. p. 189-253.

PAIVA, F. I. G. et al. Qualidade da fibra do algodoeiro BRS verde irrigado com águas de diferentes níveis salinos. Irriga, Botucatu, v. 1, n. 1, p. 209-220, 2016.

RICHARDS, L. A. Diagnosis and improvement of saline and alkali soils. Agriculture Handbook No. 60, Washington: USDA, Department of Agriculture, 1954. $160 \mathrm{p}$.

ROSALES, M. A. et al. Physiological analysis of common bean (Phaseolus vulgaris L.) cultivars uncovers characteristics related to terminal drought resistance. Plant Physiology and Biochemistry, Issy-les-Moulineaux, v. 56, n. 1, p. 24-34, 2012.

SANTOS, J. B. et al. Morfofisiologia e produção do algodoeiro herbáceo irrigado com águas salinas e adubado com nitrogênio. Comunicata Scientiae, Bom Jesus, v. 7, n. 1, p. 86-96, 2016.

SARTORI, G. M. S. et al. Rendimento de grãos e eficiência no uso de água de arroz irrigado em função da época de semeadura. Ciência Rural, Santa Maria, v. 43, n. 3, p. 397-403, 2013.

SILVA, E. C. et al. Physiological responses to salt stress in young umbu plants. Environmental and Experimental Botany, Oxford, v. 63, n. 1-3, p. 147157, 2008.

SILVA, J. L. A. et al. Uso de águas salinas como alternativa na irrigação e produção de forragem no semiárido nordestino. Revista Brasileira de Engenharia Agrícola e Ambiental, Campina Grande, v. 18, Sup., p. 66-72, 2014.

SIQUEIRA, E. C. et al. Crescimento do algodoeiro colorido sob diferentes níveis de salinidade da água de irrigação. Revista Brasileira de Engenharia
Agrícola e Ambiental, Campina Grande, v. 9, Sup., p. 263-267, 2005.

SOARES, L. A. A. et al. Fisiologia e acúmulo de fitomassa pela mamoneira submetida ao estresse salino e adubação nitrogenada. Revista Verde de Agroecologia e Desenvolvimento Sustentável, Mossoró, v. 8, n. 1, p. 247-256, 2013.

SOUSA, A. E. C. et al. Crescimento e consumo hídrico de pinhão manso sob estresse salino e doses de fósforo. Revista Ciência Agronômica, Fortaleza, v. 42 , n. 2 , p. $310-318,2011$

SOUSA, G. G. et al. Nutrição mineral e extração de nutrientes de planta de milho irrigada com água salina. Revista Brasileira de Engenharia Agrícola e Ambiental, Campina Grande, v. 14, n. 11, p. 1143 $1151,2010$.

SUASSUNA, J. F. et al. Produção de fitomassa em genótipos de citros submetidos a estresse hídrico na formação do porta-enxerto. Revista Brasileira de Engenharia Agrícola e Ambiental, Campina Grande, v. 16, n. 12, p. 1305-1313, 2012. 